\title{
DESIGNING AN ENGLISH LANGUAGE SYLLABUS FOR TEACHER EDUCATION PROGRAMS IN INDONESIA
}

\author{
Abid \\ Surel: abid@ung.ac.id
}

\begin{abstract}
This article aims at describing a sample of a syllabus design for teaching General English at the Department of Primary School Teacher Education in a university in Indonesia. The design is developed within the framework of relevant theories, such as syllabus design, language teaching and assessment. The syllabus focuses on the introduction of English language grammar. It is expected that the design can help the students of the department (henceforth refers to pre-service teachers or PSTs) to prepare themselves when enrolling into other English coursework units in the following semesters, as well as to teach English at the primary school levelin their future career as English language teachers.
\end{abstract}

Keywords: English Language, Syllabus, Teacher Education

\section{INTRODUCTION}

It is generally believed that teaching is closely related to cognitive activity. In language teaching, for instance, the activity involves the acquisition of correct grammar which assist learners to achieve proficiency in the target language. Farrel (2005) suggests that learning grammar is essential because it helps learners to use appropriate grammar in speaking and writing. Although there has been an assumption that teaching grammar can lead to monotonous and unexciting classroom, it remains essential for language teachers to build a strong linguistic foundation to help learners understand how language is used.

For this purpose, this article, therefore, aims to inform a sample of syllabus design for teaching General Englishat the Department of Primary School Teacher Education in a university in Indonesia. It is expected that the design can help the students of the department (henceforth refers to pre-service teachers or PSTs) to prepare themselves when enrolling into other English coursework units in the following semesters, as well as to teach English at primary schools in their future careers as teachers.

\section{CONTEXT TO SYLLABUS DESIGN}

This coursework unit syllabus is designed for the $1^{\text {st }}$ year PSTs of the Department of Primary School Teacher Education at a university in Indonesia, who pursue bachelor degree to become teachers at the primary school level in the future. The major aim of this unit is to prepare the PSTs to attend other coursework units inthe following years of their studies, namely English Studies and English Teaching at Primary School. It teaches them the basic knowledge of English grammar by in corporating two other skills, such as speaking and writing where

Lecturer at the Department of English Education FSB UNG 
teacher can measure the progress of students' English language grammar acquisition. Through speaking and writing, the PSTs may practice the linguistic forms they learn. This General English unit, which takes 100 minute lesson, is delivered once a week for the duration of sixteen teaching weeks.

There are approximately 3035 PSTs in the class at the department where the majority of them are young learners, aged 18 to19 years old. These PSTs, who are assumed to be beginners English language learners, are from similar linguistic backgrounds, i.e. they speak the same first language (L1), Indonesian. Therefore, lecturers can teach the English language using both L1 and L2, considering that many of these PSTs are passive English users, so the use of L1 is necessary. Burns (1992) contends that the use of LI in language classrooms may help learners, particularly low proficient ones, build confidence in learning the target language.

The use of textbooks in the department is recommended, but lecturers are given the opportunity to develop learning materials or to utilise created materials (Richards, 2001), either by adopting or combining materials from a variety of resource and highly encouraged to use other teaching resources, such as computer and OHP. Furthermore, this institution provides funds for designing course materials. This is a worthy incentive for lecturers to be more creative in designing materials for teaching.

Because learners have different needs, it is necessary to investigate what learning needs they have. In fact, as Harahap (2015) perceives, learners are complex individuals with various ways of learning styles and approaches. Thus, to address this concern, a series of procedures are carried out at the beginning of the course which involve 'collecting, organizing, analysing, and reporting the information collected' to examine the PSTs' learning needs (Richards, 2001, p. 63). Information is obtained using an 'achievement test' (Richards, 2001, p. 62), such as paper-based test and questioners. The type of questioner used is open questions (Richards, 2001). The results of the needs analysis show that the majority of the PSTs are beginners language learners. Thus, to achieve the aims and objectives of this course, it is important to assist the PSTs toimprove their basic English grammar and develop it through some constructive speaking and writing activities.

In brief, this General English unit aims to prepare PSTs to attend other English language units where more advanced grammatical forms and teaching practices are the learning focus of the units because after completing their university studies the PSTs are expected to be able to teach English at the primary school level. After following this unit, the PSTs is expected to:

1. gain an understanding of basic knowledge of English language grammar, which includes pronoun, parts of speech, count/non-count noun, simple present tense, simple past tense, present continuous tense, past 
continuous tense, simple future tense and modals.

2. be able to carry out simple English conversation and to write about simple topics, such as introducing one self, describing people and plans.

3. be able to give and understand simple instructions using English in English classrooms.

4. demonstrate the use of a range of vocabulary items that are useful in simple English conversation in the classroom context.

\section{CONTENT OF SYLLABUS}

Read (2003) suggests that in language learning, it is essential to consider what students have done before and what they will do in the future. Because the PSTs have had previous English language knowledge but many of them show low English proficiency as indicated in learners' need analysis, it might be necessary to review what they have learnt. In fact, Schultz (1999) as cited in Landis, et. al (2010) suggests that learners' experience in language learning help them participate actively in their further learning. Therefore, rebuilding their basic English grammar foundation and speaking skill enables them to engage effectively in other English language units.

On the basis of the above consideration, a structural syllabus is selected to develop this course. According to Graves (2000) the focus of structural syllabus is on how learners can master 'the grammar of the language'. It covers, for example, 'how words are classified and ordered to form phrases' (Graves, 2000, p. 44). In fact, focusing on grammar in language teaching has been embraced by some concerned educators, such as Asselin (2002) and Fitch (2001). Fitch (2001) argues that adults want to follow rules and 'often want to know the nature of the errors they are making' when learning a language. Indeed, Asselin (2002) contends that standard grammar of target language enables language learners to improve the way they communicate using the language.

In order to foster learners' ability in communicating, Graves (2000) suggests that when 'conceptualizing the content' of syllabus teacher can combine learning focuses because the general objective of teaching a language is how learner slearn and use the language being learnt. Therefore, this syllabus also highlights the importance of developing learners basic speaking and writing skills because they may need these skills when they attend other English language classes, i.e. English Teaching at Primary School where they are required to performa microteaching practice.

To design the content of this syllabus, a simple to complex approach (Richards, 2001) is selected. Richards (2001) states that in this approach, materials to be presented are organised by difficulty level, i.e. a sequence from simpler to more complex. Therefore, the PSTs are introduced to simple present tense, modals, and present continuous tense in the first six weeks prior to midterm test because these are considered less difficult for them to understand. Then, after the mid-term test, the PSTs learn future tense and past tense 
which are assumed to be rather demanding.

\section{DISCUSSION ON SAMPLE OF ACTIVITIES}

The majority of activities in this course are predominantly designed using the combination of pedagogical and real world approaches (Richards, 2001) to improve PSTs' understanding on English language grammar by incorporating speaking and writing activities as media for measuring and developing PSTs'grammatical forms acquisition. Richards (2001) suggests that pedagogical activities nurture learners' ability in mastering knowledge they learn, while real world activities provide learners with activities that are useful in their life. It is expected that the combination of these two approaches can help lecturers develop a wide range of activities which do not only foster PSTs' linguistic mastery, but also allow them to utilise the activities as models that may assist them in interacting using English in particular given contexts.

The sample of activities in this syllabus are formulated in a way that meet the goals of the unit, beliefs and context. First, the unit that includes these activities discusses simple present tense with verbin which the main goal is to enable PSTs to understand and use simple present tense to describe people and routines. This is also part of this coursework units objectives. Referring to the first activity, lecturers introduce the tense through the use of adverbs of frequency, such as always and usually. The use of these adverbs reminds PSTs that they can use simple present tense to describe about their routines. Accordingly, in the second activity, PSTs are exposed to the form of this tense by asking questions that indicate habitual actions, such as Do you work every day? and Do you wear uniform?. Besides, PSTs might often use interrogative statements in their future microteaching practice as alternative prompts for opening classroom activities.

Second, these two activities address the core assumption of this unit, i.e. that the acquisition of correct grammar assists learners to achieve proficiency in the target language (Herschensohn, 1990) and that learning grammar guides learners to speak and write grammatically in the target language (Farrel, 2005). In the first activities, the PSTs learn how simple present tense is formed, including the affirmative, negative and interrogative statements. After that, the PSTs engage in an activity where they practice asking questions using interrogative sentence and subsequently using affirmative and negative statements to introduce someone's occupation at the end of the activity. The stages in these two activities (arranging words, practicing asking questions, and describing occupation) can enhance the PSTs' ability in understanding English language grammar as well as apply it in spoken or written communication in a given context.

Third, these activities are developed by considering the context of language learners. These PSTs are categorised into beginner level. Thus, to help them understand the lesson, 
lecturers needs to design how the lesson can be understood and one way to do this is likely by creating stages of activities as discussed earlier. Also, because this is a large class, it seems helpful to put the PSTs into groups, so it can be manage able for lecturers to monitor the class. In fact, if the PSTs work in groups, there might be some PSTs who can scaffold their peers which, in turn, assist lecturers to deal with the PSTs' problems related to language uses, for instance, that appear during the lesson.

\section{ASSESSMENT}

The purpose of assessment in this course is instructional, which depicts what learners have achieved and what they still need to learn, as well as how the elements of this course are working. Thus, this purpose may assist learners to enhance their way of learning and help teachers, in particular, examine whether or not the aims and objectives of a particular course are successfully achieved. To do so, a series of assessment are carried out, i.e. progress and final achievement testing (Hughes, 1989). According to Hughes (1989), progress achievement test seeks to exam in learners' progress that they are making during a particular period of a course. This test includes mid-term test held in week eight and group work held in week fourteen. Meanwhile, final achievement test is intended to measure the overall achievement that the learners have made during a course (Hughes, 1989).

Clearly, the two tests which are mainly organised in paper based form (except for group work) and administered by staff are designed in a way that meet the aims and objectives of this unit, so they can provide meaningful descriptions of how the PSTs engage themselves in the learning process. In fact, they also need to be related to learners' needs because Brown (2008) suggests that if the tests do not represent the result of need analysis which can cause learners and teachers rejects the curriculum development, then they may all be ineffective. Most importantly, to ensure the objectivity and reliability of the tests, particularly for mid-term and final examination, statistical measurement which can be achieved through the implementation of multiple choice items is highly recommended (Heaton, 1988), whereas for group work, analytic scales (Hughes, 1989) is utilised.

Another essential test that is included in this unit is diagnostic tests. Hughes (1989) states that this test is utilised to figure outlearners' strengths and weaknesses. From this test, teacher may design what further teaching is significant in order to address learners' strengths and weaknesses. This test is conducted at the beginning of the coursework unit, i.e. in week one. The form of this test is multiple choice items and a questionnaire.

The assessment of this unitis as follows:

Table 1 Assessment

\begin{tabular}{|l|c|}
\hline Assessment items & $\begin{array}{l}\text { Weighting (total } \\
\text { to equal 100\%) }\end{array}$ \\
\hline Attendance & $10 \%$ \\
\hline Group work & $15 \%$ \\
\hline $\begin{array}{l}\text { Mid-term } \\
\text { examination }\end{array}$ & $35 \%$ \\
\hline Final examination & $40 \%$ \\
\hline
\end{tabular}


Attendance: The PSTs are expected to attend on regular basis, but a less than $75 \%$ of attendance will result in prohibition of taking final examination which may cause them to have difficulty in passing this unit. This is based on the institution policy of the department. Yet, a special arrangement can be made, particularly for PSTs who are unable to attend classes due to some special circumstances, such as medical condition and private commitment. Therefore, earlier reasonable notice regarding absence is required.

Group work: The PSTs are also assessed individually through groupwork. This type of assessment is intended to measure their English grammar acquisition through speaking activity. The task is to create a conversation where the PSTs are required to use all grammatical items they have learnt during this course. The PSTs have the opportunity to decide on a topic they prefer and to design a preferable way to begin their 10 minutes conversation. Some items to be assessed from this type of assessment are grammar, vocabulary and comprehension with the scale of scoring ranging from 1 (the lowest proficiency) to 6 (the highest proficiency) (Hughes, 1989).

Mid-term examination: Mid-term examination is one major test of this course which is held in week eight and addresses the knowledge that the PSTs have learnt from week two until week six. The test duration is 100 minutes and administered by staff of this department. The test mainly consists of 35 multiple choice items and a writing part. However, for multiple choice items, lecturers may design the test by incorporating another type of instruction, i.e. identifying an incorrect verb, noun, or adjective.

Final examination: This examination has similar form of test (instruction and duration) with the mid-term examination. It tests PSTs' understanding of knowledge that they have obtained from week nine until week thirteen.

The scale of scoring for passing this unit complies with this institution policy, as shown in the following table:

Table 2 Scoring

\begin{tabular}{|c|c|}
\hline Score & Rating \\
\hline $85-100$ & A/High distinction \\
\hline $70-84$ & B/Distinction \\
\hline $55-69$ & C/Credit \\
\hline$<55$ & D/Fail \\
\hline
\end{tabular}

\section{EVALUATION}

To ensure that the delivery of thisunit is successful, it is significant to carry out an evaluation which provides a description of how theelements of this syllabus work (Richards, 2001) as well as proposes further meaningful and effective development (Kiely, 2009). The focus of the evaluation is on syllabus content, materials of instruction, the learners' progress and the teachers (Richards, 2001). Summative approach isselected to evaluate the implementation of this syllabus.

There are a number of procedures in collecting data for this unit evaluation. These are: 
1. Tests (Richards, 2001)

All type of tests in this unit is to be used to evaluate the achievement of the PSTs. The PSTs' results (grades) may help lecturer to recognise whether or not the aims and objectives of this unit are successfully achieved. Although it is realised that others factors (e.g. lecturers' performance and material) can influence how the PSTs perform on the tests,at least, these tests enable lecturers to obtain a direct measurement of the PSTs' achievement (Richards, 2001).

2. Learners' evaluation (Richards, 2001)

This is another significant input that can be used to measure how this unit is delivered. PSTs are asked to provide written feedback on the unit delivery by giving some comments on various aspects, such as lecturers' teaching approaches and the learning resources used in the classroom (Rachmadyanti, 2017).

\section{CONCLUSION}

This article aims at informing lecturers, in particular, on the design of an English language syllabus for teacher education programs at the university level. The syllabus designed reported in this article is from a General English coursework unit at the Department of Primary School Teacher Education in a university in Gorontalo, Indonesia. The design of the syllabus is expected to assist the PSTs, upon the completion of the unit, in developing their basic understanding of English language grammar so that they can find ways to engage in the given contexts of English uses situated in Indonesia.

\section{REFERENCES}

Asselin, M. 2002. Teaching Grammar. Teacher librarian, 29 (5).

Brown, J. D. 2008. Testing-context Analysis: Assessment Is Just Another Part Of Language Curriculum Development. Language Assessment Quarterly, 5(4), 275-312.

Farrel, T.S.C. 2005. Conceptions of Grammar Teaching: A Case Study Of Teachers' Beliefs And Classroom Practices. TESL EJ, 9(2).

Fitch, D. A. 2001. Teaching Grammar To Adults And Second Language Learning Research. Education, 116(1), 32-34.

Graves, K. 2000. Designing Language Courses: A Guide for Teachers. Boston, MA: Heinle and Heinle.

Harahap, G.R. 2015. Peningkatan Keterampilan Guru Dalam Penerapan Pakem Melalui Pelatihan Dan Bimbingan Kepala Sekolah di SD Negeri 101774 Sampali [Teachers' capacity development in implementing PAKEM via school principal training and supervision at the SD Negeri 101774 Sampali]. Elementary School Journal, 4(1), 126-135. doi:

10.24114/esjpgsd.v4i1.2908 
Abid: Designing an English Language Syllabus ..

Kiely, R. 2009. Small Answer To The Big Question: Learning From Language Program Evaluation. Language teaching research, 13(1), 99-116.

Landis, D., Umolu, J. and Mancha, S. 2010. The Power Of Language Experience For CrossCultural Reading And Writing. The reading teacher, 63(7), 580-589.

Rachmadyanti, P. 2017. Peningkatan Kualitas Pengelolaan Kelas Melalui Manajemen Display Kreatif Bagi Kelompok Kerja Guru SD KecamatanPakal Kota Surabaya [Classroom Management Development Via Creative Display Management For Primary School Teachers Group Work In Pakal Kota Surabaya]. Elementary School Journal, 7(1), 1-8. doi: 10.24114/esjpgsd.v7i1.6396

Read, C. 2003. Towards whole learning. IATEFL SIGs newsletter, 47-50.

Richards, J. 2001. Curriculum Development in Language Teaching. Cambridge: Cambridge University Press. 